\title{
DIE VERHOUDING VAN GEN. 1 EN GEN. 3 IN DIE KONINKRYKSBESKOUING
}

\author{
Literatuur wat hier hoofsaaklik onder die soeklig is:
}

S. du Toit: Die Koninkryk van God in die Ou Testament, in: die koninkryk van God, red. S. du Toit e.a., Potchefstroom 1969 (hier aangehaal as $\mathrm{KG}$ ).

S. du Toit: Bybel, Skepping, Evolusie, Tweede hersiene en uitgebreide uitgawe, Voortrekkerpers 1968 (hier aangehaal as BSE).

S. du Toit: Openbaringsgeskiedenis van die Ou Testament, Vierde hersiene en uitgebreide druk, Potchefstroom 1969 (hier aangehaal as OOT).

1. Die verklaring van Gen. $1: 2$ is van deurslaggewende betekenis vir die Koninkryksbeskouing.

Skrywer (so sal telkens na die skrywer van bogenoemde werke verwys word) sê aangaande Gen. $1: 2$ die volgende: „Hierdie vers is van deurslaggewende belang in verband met die verkondiging van die Skrif aangaande die skepping en die voleinding" (BSE, 159). Voorts: „Direk aan die begin word - volgens die oortuiging van die skrywer hiervan - ook bose magte, ,teëspelers" van die Koning - gesinjaleer en wel in die tohû wabohû (Gen. 1:2)" (KG, 14). En verder: „Die Satan en sy werk van die begin af tot die einde. Maar sy mag deur Christus gebreek - siedaar die grondtema van die Skrif!" (BSE, 174).

2. Skrywer sien tohu, bohu, tehoom, duisternis en selfs die waters as demoniese magte.

„Samevattend sou ons wil sê dat as die betekenis van woorde in die res van die Ou Testament in aanmerking geneem word, daar geen twyfel behoort te wees dat die woorde ,tohu', ,bohu', ,tehoom' en duisternis onheilspellende magte aandui nie. Dat die ,ruach elohim' hier een of ander uitwerking uitgeoefen het, is duidelik maar dit bly nog onduidelik wat die werking presies was. $\mathrm{Na}$ ons oortuiging moet hierdie vers in verband gebring word met die tekste uit die digterlike boeke, wat verwys na 'n stryd van God met monsters" (BSE, 168).

Ook ,die water is 'n bedreigende mag (vgl. die verklaring van Gen. $1: 2$ ). Dit het iets onheilspellends".

,As God sy oordele oor die mensdom laat kom, word (hier) die skeiding momenteel weer weggeneem - bv. in die van die sondvloed".

„In die werk van die tweede dag en die eerste werk van die derde dag kan die breideling van die ,chaotiese' magte gesien word om so die aarde voor te berei as woonplek van die mens. Slegs as die Woord van God hulle teëhou bly die magte op hulle toegewese plek" (OOT, 72). 
Skrywer neem (teenoor Kroeze) nie „stryd by die skepping” aan nie, maar verkies ,stryd na die (eerste) skepping (BSE, 171).

Van die syns insiens ter sake aangehaalde digterlike gedeeltes sê hy: „Ons het in die meeste gevalle met digterlike beelde te doen en daarmee moet rekening gehou word. Maar die digter verwys in sy beelde tog na iets wat gebeur het, anders is daar geen sin in nie (BSE, 172).

„Die Satan en sy werk van die begin af tot die einde. Maar sy mag deur Christus gebreek - siedaar die grondtema van die Skrif!" (BSE, 174).

„Elke uitspraak van God: ,en God het gesien dat dit goed was', beteken dan soveel as 'n kreet van oorwinning hoewel daar geen stryd was nie. Met elke skeppingsdaad word aan hierdie magte paal en perk gestel.

Daar moet op gelet word dat die magte nie vernietig word nie. Hulle bly altyd 'n bedreiging. Die mag van Satan word dus vanaf Gen. $1: 2$ gesien tot aan die voleinding.

As dit aanvaar word, het ons ook die verklaring van die bestaan van monsters in die skepping van God en vir die baie abnormaliteite waarvoor ons geen oplossing het nie as Gen. $1: 2$ bloot op 'n ongevormde toestand dui" (BSE, 176).

„Maar - soos bo aangetoon - gee die Skrif wel aanduidinge, al is dit in beeldtaal, dat God sy magswoord moes spreek oor magte van die duisternis reeds voordat die mens nog daar was" (BSE, 176).

Skrywer wil saam met Koole - teenoor N. H. Ridderbos - die „baie goed" in Gen. 1 nie laat ,sien op die tyd voor die sondeval (van die mens)" nie. Daar is asembenemende natuurrampe (volgens geoloë) waarin kuddes voorwêreldlike diere omgekom het, wat nie op rekening van die sondeval van die mens geplaas kan word nie. Dieselfde geld van parasitering van diere op mekaar (BSE, 175).

Daar was nie orals op aarde ' $n$ staat van onderlinge vrede voor die sondeval van die mens nie. Die Paradys was 'n „baie aparte, van die normale aarde geskeie, spesiaal aangelegde, beperkte gebied" (OOT, 86).

Die toestand van Gen. 1 is volgens hom 'n bestendige. (Hiervoor verwys hy na Spr. $8: 23-29$; Ps. 8). (BSE, 175).

„In duisternis en nag is daar nog reste van die toestand van Gen. 1 : 2" (OOT, 70).

Skrywer se standpunt kom dus op die volgende neer: God het hemel en aarde geskape (Gen. $1: 1$ ). Die beskrywing van die toestand van die aarde wat onmiddellik volg en wat ons natuurlikerwys sou wil aanvaar as beskrywing van die toestand soos God dit geskape het, beskryf in der waarheid (onverwags) 'n ander toestand, nl. 'n demoniese, vanweë die intrede wat Satan ondertussen gedoen het (op 'n wyse wat Genesis self nie verklaar nie). Tohu, bohu, tehoom, duisternis en water (Gen. $1: 2$ ) is onheilspellende, sataniese magte.

Die woorde na elke (ses-)daagse skeppingswerk van God: „en dit was goed", is 'n Goddelike oorwinningskreet oor die demoniese, 
sataniese magte. Dit beteken nie dat hulle vernietig word nie, maar slegs dat daar aan hulle perke gestel word. Daar kan dus wel natuurrampe voorkom, diere kan op mekaar parasiteer, duisternis en nag het (nou) nog reste van dié demoniese toestand.

Satan laat dus, afgesien van ' $n$ eventuele sondeval van die mens, nie alleen sy bedreigende invloed geld nie, maar ook 'n verwoestende - al is daar sekere perke aan gestel.

3. Die betekenis wat die Skrywer aan tohu in Gen. $1: 2$ toeken, is strydig met die betekenis daarvan elders in die O.T.

Skrywer beroep hom op die betekenis van die tohu elders in die Skrif en beweer myns insiens sonder grond dat dit daar nie 'n onskuldige betekenis (in die sin van nie-demonies) het nie.

Ek verwys na my artikel: „, Woes en Leeg' en ,Duisternis' in Genesis I (het die demoniese betekenis?)", In die Skriflig 2, Febr. $1967,3-15$, en doen hier enige onderstrepings en aanvullings. Daar is slegs twee ander plekke waar tohu en bohu verbonde voorkom, naamlik Jer. $4: 23$ en Jes. $34: 11$. Hier is egter geen sprake van 'n aktiewe vyandskap (teen God en Sy skepsel, die mens) nie, geen vyandige demoniese ,mag" nie, maar van 'n toestand van nietigheid, niksheid of woestheid in die sin van verlatenheid, onherbergsaamheid, en wel as resultaat van die oordeel van God. Jer. 4: 23 lui: „Ek het na die aarde gekyk, en dit was woes en leeg (tohu wabohu); ook na die hemel, en sy lig was daar nie". Vergelyk veral vs. 26: „Ek het gekyk, en die land van tuine was 'n woestyn, en al sy stede was afgebreek voor Jahwe, voor sy toorngloed".

Jes. 34 : 11 spreek van die toestand wanneer Jahwe ,'n dag van wraak, 'n jaar van vergelding in die regsaak van Sion" hou. Van Edom sal dan geld: „En $\mathrm{Hy}$ sal die riglyn van woestheid en die skietlood van vormloosheid (qaw-tohu w'abne-bohu) daaroor span".

Daar moet in gedagte gehou word dat indien tohu wabohu in Gen. 1 : 2 'n demoniese mag sou aandui, dit primer 'n vyandskap teen God sou wees, nie teen die mens nie. Daar kan moeilik beweer word dat Satan probeer verhoed het dat God die aarde vir die mens 'n woonplek sou maak. Gen. 1 : 26 leer ons dat God eers op 'n gevorderde stadium van die sesdaagse skeppingswerk, naamlik onmiddellik voor die skepping van die mens. sy gedagte bekend gemaak het om 'n mens te skep. Eers in hierdie stadium hou God ' $n$ beraadslaging om dit te doen. Hieruit blyk in elk geval dat hierdie beplanning nog nie vir Satan bekend was nie.

As die (deur die skrywer beweerde) vyandskap (tohu wabohu) van Gen. $1: 2$ dus nie anders as primêr teen God (nie teen die mens) gerig sou kon wees nie, volg hieruit dat die tohu wabohu wat die vrug is van die oordeel van God oor Jerusalem (Jer. $4: 23$ ) en Edom (Jes. 34 : 11) primêr 'n sataniese magsbeoefening teen God self sou wees!

In Jes. en Jer. is tohu wabohu 'n toestand wat die vrug is van die werksaamheid van God. Die skrywer verander dit in Gen. $1: 2$ 
en maak dit 'n magsbeoefening met Satan as subjek (en God as indirekte objek).

Die eenvoudigste en voor die hand liggende betekenis is om in aldrie die gevalle tohu wabohu te sien as 'n toestand wat die vrug is van ' $n$ werksaamheid waarvan God die subjek is. Maar dan is daar geen moontlikheid dat tohu wabohu in Gen. 1 : 2 'n demo. niese mag (of selfs 'n toestand wat die vrug van sodanige mag is), kan aandui nie.

(Die skrywer sou - bloot uit die vergelyking van die betekenis van tohu wabohu in Gen. $1: 2$ met dié in Jes. $34: 11$ en Jer. $4: 23$ - myns insiens meer grond gehad het vir 'n bewering dat Gen. $1: 2$ die vrug is van Gods oordeel oor...(?).)

Die woord tohu kom veral in die tweede deel van Jesaja voor ( 7 keer in Jes. $40-55$ en 1 keer in Jes. 59). Hierdie Skrifgedeelte gryp gedurig op die skepping terug en vergelyk gedurig Gods verlossingswerk aan sy volk met sy skeppingswerk. As tohu wabohu in Gen. 1:2 demonies sou wees, sou ons dus verwag dat Jes. 40 vgl. met sy sterk teruggrype op Gods skeppingsaktiwiteite, en sy voorliefde vir die woord tohu, hierdie demoniese beteken is van tohu duidelik aan die lig sal laat kom. Die teendeel is egter waar: nêrens is daar enige sprake van tohu as 'n demoniese mag nie.

Die volgende word as tohu aangedui:

1. Nasies ( $40: 17)$; parallel met ajin en efes (niks, nietigheid). Hulle is soos 'n druppel aan die emmer, soos 'n stoffie aan die weegskaal - dus, vir God geen faktor om mee rekening te hou nie. (,,Al die nasies is voor Hom soos niks (ajin); as niks (efes) en nietigheid (tohu) word hulle by Hom gereken".)

2. Vorste (40:23); parallel met ajin (niks, nietigheid). Hy gee hulle aan die verganklikheid prys. Hulle is vir God geen faktor om mee rekening te hou nie. (,Hy maak die vorste tot niet, die heersers van die aarde verander $\mathrm{Hy}$ in nietigheid; skaars is hulle geplant, skaars is hulle gesaai, skaars wortel hulle stam in die grond, of $\mathrm{Hy}$ blaas op hulle, sodat hulle verdor, en die storm voer hulle weg soos 'n stoppel").

(Hierdie vers moet in die nouste verband gesien word met die voorafgaande: „Hy sit bo die kring van die aarde, en die bewoners daarvan is soos sprinkane; Hy span die hemele uit soos 'n dun doek en sprei dit uit soos 'n tent om in te woon". Hier word die belaglikheid van die mense uitgebeeld wat soos sprinkane met hulle krom spronge probeer om bokant die ander uit te styg, maar weer tussen die ander te lande kom (Calvyn). Met ander woorde hulle is maar deel van die groot wemelende aardse massa. As ons hierdie verklaring aanvaar, beteken dit dat vers 23 , voortgaande hierop, nou uitdruklik praat van dié wat die krom spronge gee en slegs momenteel uitstyg, naamlik die vorste. Hulle word deur God gemaak soos alle ander mense - „,alle vlees", Jes. 40 : 6-8 - naamlik aan die verganklikheid prysgegee. Hier is egter nie sprake van 'n 
aktiewe daad van vernietiging deur God nie - soos bv. 'n oordeelsdaad nie - net so min as in Jes. $40: 6-8$. Trouens tohu het nêrens in die O.T. so ' $n$ betekenis nie. Dit het betrekking op die bestaansnietigheid. Daar is dus niks wat dié vorste van die massa nietige mensdom onderskei nie. Hulle onderskeidende element is maar soos die spronge van 'n sprinkaan of die aanvalligheid van 'n verganklike blom. Die teenoorgestelde van tohu sou wees dat hulle wel iets het wat hulle van die massa onderskei. Hierdie nie-onderskeidende betekeniselement van tohu vind ons ook in Gen. 1:2 waar die dinge nog nie geskeie en onderskeie is nie. Afgesien van hierdie perspektief van dié vers is dit egter duidelik dat tohu hier beslis geen demoniese betekenis het nie. Daarom laat ek dit vir die doel van hierdie artikel by 'n terloopse opmerking.)

3. Swygende gode (41:29); parallel met awen, efes en wind. Hulle kan niks uit die verlede vir die huidige situasie sê nie, ook niks vir die toekoms nie; hulle kan dus geen doel of bestemming vir die gebeurtenisse aanwys nie. (,Kyk, hulle almal is niks (awen), hulle werke is niks (efes), wind en nietigheid (tohu) is hulle gegote beelde".)

4. Beelde-makers (44:9); wat geen voordeel bring nie, niks sien nie en niks weet nie. (,Hulle wat gesnede beelde maak, is almal nietigheid (tohu), en hulle lieflinge bring geen voordeel nie; en hulle getuies - dié sien niks en weet niks, sodat hulle beskaamd staan".)

Die volgende word as nie-tohu beskou:

1. Die deur God geskape bewoonbare aarde (45:18). Hier word die teenstelling tohu en nie-tohu duidelik gesien as bewoonbaar en nie-bewoonbaar. (,Want so sê Jahwe, wat die hemele geskape het - Hy is God! - wat die aarde geformeer en dit gemaak het - $\mathrm{Hy}$ het dit bevestig; Hy het dit nie geskape om woes te wees (lo-tohu) nie, maar dit geformeer om bewoon te word".)

Hoe ver die betekenis van tohu hier van iets demonies verwyder is, blyk verder ook duidelik uit die volgende vers waar nie-tohu gebruik word in verband met:

2. Gods openbaring aan sy bondsvolk (45:19). (,Ek het in die geheim nie gespreek nie - op die plek van die donker land; Ek het aan die geslag van Jakob nie gesê: Soek My tevergeefs (tohu) nie. Ek is Jahwe wat geregtigheid (= verlossende geregtigheid) spreek, wat regte dinge verkondig".)

Dit kom verder ook duidelik uit in die feit dat tohu met die taak van die Lydende $\mathrm{Kneg}$ in verband gebring word (49:4): „Maar Ek het gesê: Tevergeefs (lerieq) het Ek My vermoei, My $\mathrm{krag}$ vir niks (l'tohu) en vrugteloos (hebel) verteer! Nogtans is My reg by Jahwe, en My loon is by My God". Hierdie Kneg se mond is deur God "gemaak soos skerp swaard". God het Hom 'n skerp pyl gemaak (Jes. $49: 2$ ). Met ander woorde Hy verkondig Gods woord 
en is Gods woord. Hierdie woord wat uit Gods mond uitgaan, keer egter nie leeg (rēqaam, vgl. lerieq in $49: 4$ ) na God terug nie, maar doen wat Hom behaag en is voorspoedig in alles waartoe Hy dit stuur (Jes. $55: 11$ ).

Tohu beteken hier dus leegheid, sinloosheid, doelloosheid. Gods woord verander egter so 'n toestand en gee doel (Hy laat voorspoedig wees) (Jes. $55: 11$ ) en volheid (versadiging) (Jes. $55: 2,10$ ).

4. Skrywer se verklaring van tohu wabohu is strydig met die swaar aksent van die hele Gen. 1 op die Goddelike inisiatief en aktiwiteit, die onmiddellike effektiwiteit van sy skeppingsoptrede en die onmiddellike gehoorsame response van die geskape dinge daarop.

Die naam „God" word telkens uitdruklik genoem. In die 34 verse van Gen. 1: 1 tot $2: 3$ klink dit soos 'n refrein God ... God ... God (naamlik 35 keer!) Daar word selfs baie weinig na God verwys as „Hy" of „Hom" (slegs in 1: 10, 27, 31; 2:2, 3). Die skrywer wys die leser gedurig op die mees direkte wyse na God en sy optrede.

Op Gods skeppingsoptrede volg telkens onmiddellik woorde soos: „en dit was so", „en daar was...", „toe sien God dat dit goed was".

Daar is slegs een keer sprake van dinamiek of inisiatief van die geskapene (,die aarde het voortgebring grasspruitjies...", vs. 12), en dan ook alleen as resultaat van response op die Goddelike dinamiek of inisiatief. In die ander gevalle word daar volstaan met die Goddelike opdrag en die woorde: „En dit was so”, of: „Toe sien God dat dit goed was".

Daar is dus in hierdie hoofstuk ' $n$ implisiete maar baie duidelike ontkenning van enige inisiatief van die geskapene.

Die beskrywing van die aarde as tohu wabohu (Gen. $1: 2$ ) volg onmiddellik na die woorde: „In die begin het God die hemel en die aarde geskape" (Gen. $1: 1$ ). Om dit as aanduiding van iets demonies te sien, is om 'n negatiewe reaksie of inisiatief van die geskapene teenoor Gods daad te aanvaar, wat strydig is met bogenoemde aksent van Gen. 1.

Gen. 1 : 2 wil ook nie sê dat hierdie toestand een is wat na die eerste skeppingsdaad van God (Gen. 1 : 1) so geword het nie (waarop skrywer se beskouing neerkom). Want dan sou ons die waw consecutief-konstruksie saam met die imperfektum-vorm van haja verwag (wattehi). Hier word egter die perfektum gebruik (hajeta).

Die toestand van Gen. 1 : 2 staan nie demonies-vreemd teenoor God nie, soos blyk uit die derde gedeelte van die vers: ,en die Gees van God het gesweef op die waters". Hierdie gedeelte is nie in anti-tese teenoor die eerste gedeelte (tohu wabohu) nie. Die vers vorm grammatikaal 'n eenheid. Dit het geen aktiewe werkwoord nie, maar slegs die hulpwerkwoord "was" aan die begin en die participium „swewend" (Afr. vertaling: „gesweef") in die derde sinsdeel: „En die aarde was tohu wabohu en duisternis op die 
wêreldvloed en die Gees van God swewend op die waters".

Die $\sin$ is duidelik as dit so verstaan word dat Gen. $1: 2$ die toestand beskryf wat 'n onmiddellike resultaat was van Gods skeppingsaktiwiteit (Gen. 1:1) en waarin God nog voortgaande 'n sekere aktiwiteit uitgeoefen het.

Hierdie toestand was egter nog 'n voorlopige. Dit lê in 'n sekere sin ook opgesluit in die woord haja wat nie die inherente hoedanigheid van iets aandui nie, maar die veranderlike, vergelyk byvoorbeeld Jona $3: 3$ : „En Nineve was 'n ontsaglike groot stad” (ondertussen het die toestand egter verander). Ons kan dus vry vertaal: „En die aarde was nog tohu wabohu ens."

Dit is dus verstaanbaar dat die kenmerkende refrein: „toe sien God dat dit goed was", nie na die beskrywing van hierdie (nog) onherbergsame toestand van die aarde volg nie.

Die mees voor die hand liggende wyse om te verklaar wat in Gen. $1: 2$ bedoel word, is om te vra wat volgens Gen. 1 'n toestand is wat nie tohu wabohu is nie, met ander woorde watter verandering God aan dié toestand gebring het. Daaruit blyk dan dat dit die toestand is waarin geen lig is nie, geen skeidinge (tussen lig en duisternis, tussen water bo en onder die uitspansel, tussen water en land), geen plante, geen ligdraers, geen lewe: van visse, voëls, diere of mens. Dit is nog heeltemal iets anders as demonies.

Die skrywer verklaar nie hoe die toestand van die aarde wat God geskep het (Gen. 1: 1), was voordat die Satan sou ingetree het nie. Hierdie swye lê voor die hand as aanvaar word dat die Skrif daaroor swyg.

Tog duik 'n belangrike probleem hier op. Volgens die skrywer se verklaring kon dié toestand nie tohu wabohu gewees het nie. Ook die duisternis (volgens hom eweneens 'n bose mag) kon nie daar gewees het nie. Maar wat was daar dan? Was daar lig? Dit sou myns insiens moeilik gerym kon word met Gen. 1:4 waarvolgens die lig blykbaar op die eerste skeppingsdag (van die sesdaagse skeppingswerk) vir die eerste keer op die aarde verskyn het, soos blyk uit die woorde: "Toe sien God dat die lig goed was”.

As daar na die skepping van God in Gen. 1: 1 nog nie lig was nie, bly slegs duisternis oor - vir die goeie skepping van God (Gen. 1: 1). Maar dan verval een van die belangrikste motiveringe van die skrywer in verband met demoniese magte in Gen. 1: 2 .

5. Skrywer se verklaring van Gen. 1 : 2 vgl. impliseer dat 'n afwisselingsverhouding en balansering van goed en kwaad vir God "goed" is - strydig met die antitetiese verhouding waarin die O.T. goed en kwaad stel.

Die toestand van die aarde voor die sesdaagse skeppingsaktiwiteit van God is, volgens bogenoemde beskouing, demonies, die werk van Satan. God se sesdaagse skeppingsaktiwiteit bring nie 'n fundamentele vernietiging of selfs fundamentele oorwinning van die magte nie. Hulle veroorsaak nog natuurrampe en lei tot parasitering van diere onderling. Selfs vandag nog bestaan die reste daarvan 
in nag en duisternis. (En dit geld blykbaar ook van die toestand in die Paradys, want Gen. $3: 8$ impliseer duidelik dat daarin ook 'n afwisseling van dag en nag was; vgl. ,aandwindjie”; lett.: „die dagwind" (ruach hajjom)).

God tree ook nie anti-teties teenoor die demoniese magte op nie. Hy laat die sataniese duisternis nog steeds elke nag sy heerskappy behou. Gods oorwinning bestaan daarin dat $\mathrm{Hy}$ hierdie sataniese duisternis afwissel met die goeie lig, met ander woorde dat Hy 'n balans tussen die twee bring. En dis nie maar 'n tydelike of voorlopige aksie van God nie - nêrens is daarvan enige sweem in Gen. 1 te bemerk nie. Dit is as blywende toestand bedoel. Bowendien ontvang hierdie afwisselingsverhouding, hierdie balans die besonder sterk en gunstige waardebeoordeling van God dat dit "goed" ja, selfs "baie goed" is. Sataniese en nie-sataniese, die goeie en die bose, staan dus wel as twee pole teenoor mekaar; in die groot geheel gesien egter nie antiteties nie, maar as twee pole langs mekaar wat saam in hulle gedurige en konstante afwisseling en "baie goeie" harmoniese elips en balans vorm.

Myns insiens kan dit nie anders as dat die implikasies van hierdie beskouing verreikende gevolge vir die koninkryksbeskouing sal hê nie. Want dit relativeer die ,baie goeie" skepping van God (Gen. 1) tot iets waaraan daar belangrike beperkinge is weens die magsuitoefening van Satan.

Dit moet uiteindelik lei tot ' $n$ mate van relativering van die absoluut antitetiese verhouding van die goeie en kwade in die koninkryk - in elk geval vir hierdie aarde.

Dit moet ook uiteindelik vergenoegd wees met 'n koninkryk waarin nie vernietiging van die bose nagestreef word nie, maar ' $n$ balans van tyd-like (tydmatige) of ruimtelike afwisseling van goed en kwaad.

6. Hierdie beskouing raak in dié warnet omdat dit in verband met die verhouding koninkryk en anti-koninkryk 'n aksent in Gen. 1 lê wat die Skrif eers in Gen. 3 doen: ná die skepping van die mens en sy sondeval.

Die Skrifaksent is dat die verbreking van die persoonlike band van die mens met God deur die ongehoorsaamheid van die mens, die oorsaak is van die ellende van die mensdom en die aarde: „vervloek is die aarde (aardbodem) om jou ontwil ..." (Gen. $3: 17$ ). Die gees van die O.T. is deurgaans dat lyde in hierdie wêreld gesien word onder die aspek van menslike skuld. Daar is nêrens sprake van dat die mens in mindere of meerdere mate 'n soort slagoffer is van kosmiese magte nie.

Selfs in die menslike sondeval waarin 'n dier as instrument deur Satan gebruik is, is die mens nie sodanige slagoffer nie, maar ongehoorsame.

Skrywer se beskouing kom daarop neer dat die mens na sy val in die Paradys oorgegee word aan die aarde waarin demoniese magte reeds gewerk het voor sy sondeval. 
Deur die skrywer se beskouing kom Satan en die sataniese te sentraal in Gods skepping te staan en te primêr ten opsigte van die koninkryk. Volgens hierdie verklaring is die eerste woord wat ons van hierdie aarde hoor (benewens die feit dat God dit geskape het, Gen. 1 : 1): demonies, Satan! Selfs God se sesdaagse skeppingsaktiwiteit laat die demoniese nog (in mindere of meerdere mate) bly.

Hierdie sentraalstelling van Satan en die demoniese kom ook heel konkreet uit in die reeds aangehaalde stelling in BSE, 174: „Die Satan en sy werk van die begin af tot die einde. Maar sy mag deur Christus gebreek - siedaar die grondtema van die Skrif!" Myns insiens word God hiermee te veel uit die sentrale plek verdring en te primêr 'n Teëhouer van Satan gemaak. Die grondtema van die Skrif is veeleer: God en sy werk van die begin af tot die einde toe. Daardie werk is deur Satan teengestaan, maar sy mag is deur God, deur Christus, verbreek. Dit kom myns insiens ook openbaringshistories daarin uit dat Gen. $1-3$ ons leer dat die aarde Gods goeie skepping is, dat die Satan ná die sesdaagse skeppingswerk via die sondeval van die mens, sy intrede gedoen het, maar dat sy mag deur God, deur Christus, vernietig word.

7. Die versoening van die mens met God - en gevolglik die kruis van Christus en die kerk - word verdring uit die sentrum (mediaal gesien) van die koninkryksbeskouing en kom in mindere of meerdere mate parallel te staan met kosmiese magte of werkinge (Gen. 1). Dus, 'n koninkryk in mindere of meerdere mate buite kerk en kruis om.

Dit gaan volgens die aksent van Gen. $1-3$ sentraal om die soewereiniteit van God. Sy soewereiniteit vind 'n belangrike toespitsing in die mens, die kroon van sy skepping, wat na sy beeld geskape is. Hier kom twee belangrike faktore na vore. Eerstens, Gods heerskappy word in besonder uitgeoefen in en deur die mens. Tweedens, dit geskied langs die weg van verbondsgemeenskap met en deur die mens wat sy beeld is.

Dit is die verbreking hiervan wat die vervloeking van die aarde (Gen. 3) en die saak van koninkryk-anti-koninkryk tot gevolg het. Dit is ook alleen deur die herstel hiervan wat sake weer reggestel kan word, d.w.s. deur die versoening van die gevalle, absoluut doemwaardige mens met God (Gen. $3: 15 ; 6: 15-17 ; 8: 21$; ens.).

In verhouding tot die versoening van die aarde met God, staan dié van die mens dus sentraal, in die sin van mediaal, in die koninkryk. Dit is alleen deur die versoening van die mens se sondes deur Jesus Christus (Rom. 8: 1 vlg.) wat die hele skepping van sy sugte en barensnood verlos word (Rom. $8: 22$ ).

Deur die bespreekte beskouing (wat Gen. $1: 2$ as demoniese toestand verstaan) tree hierdie versoening van die mens met God uit die sentrum van die koninkryksbeskouing en staan in mindere of meerdere mate parallel met demoniese kosmiese magte en werkinge (Gen. 1).

Want daarvolgens is die menslike sondeval nie die enigsto 
oorsaak van aardse kosmiese, demoniese magswerkinge en gevolg. lik van lyde nie, en daarom is die mens se versoening met God ook nie die enigste sentrum van waaruit alles, ook alle aardse kosmiese dinge, met God versoen word en tot volle harmonie gebring word nie.

Daar is dus koninkryksafbraak en koninkryksbou op aarde moontlik buite die mens en sy sonde en sy versoening om - soos byvoorbeeld deur kosmiese aan bande-legging van duisternis.

Dit kan myns insiens nie anders as dat genoemde beskouing tot ' $n$ relativering van die menslike sondeval en sonde moet lei nie.

Die versoening van die mensdom met God kan nie meer die enigste sentrum wees van waaruit God sy koninkryk op aarde bou nie; die kerk as versoende volk van God kan dit gevolglik ook nie wees nie; ook nie die kruis van Christus nie. Hier tree 'n dualisme en parallelisering tussen koninkryk en kerk na vore. Hier kry ons 'n koninkryk in sekere sin buite die kruis om.

8. Die koninkryk kry iets van 'n onpersoonlike aksent: die verhouding van staat teenoor burgers (na die patroon van 'n aardse koninkryk), die verbond tree terug, en die persoonlike gemeenskap tussen God en mens (individu) (vader-kind) tree te veel op die agtergrond.

Genoemde beskouing plaas vir die koninkryk 'n besondere sterk aksent op kosmiese magte en werkinge, of magte in kosmiese werkinge (buite die mens en sy sondeval en versoening om). God se gemeenskap met die mens, verbondsgemeenskap, tree daarmee te veel op die agtergrond. Die aksent val te veel op koninkryks- en anti-koninkryksmagte. Daarmee kry die koninkryk iets van 'n onpersoonlike aksent: dit word of neig na 'n verhouding van staat en burgers (na die patroon van 'n aardse koninkryk). Anders gestel: omdat die kwaad in die skepping losgemaak word van die sondeval van die mens, neig die beskouing daartoe dat die mens se godsdienstige lewe buite die koninkryk te staan kom. Die koninkryk het dan te doen met ontworsteling van die aarde aan die duistere magte (deur tegniek en beskawing?) terwyl die godsdiens 'n privaatsaak word tussen God en mens.

Die implikasies hiervan vir die prediking is voor die hand liggend. Dit moet of lei tot ' $n$ verontpersoonlikende versaakliking daarvan (koninkryksprediking) enersyds, ò tot 'n verindiwidualiseerde versubjektivering daarvan (godsdienstige lewe) andersyds; of tot 'n dualisme.

Dit skyn vir my of die skrywer in elk geval nie aan die eerste gevaar ontkom het nie. Sy „Openbaringsgeskiedenis van die O.T." openbaar - in die geheel gesien - myns insiens twee belangrike leemtes: die verbond en die persoonlike gemeenskap tussen God en mens ontvang te weinig aandag (versaakliking). En as die skrywer wel die belangrikheid van die persoonlike gemeenskap tussen God en mens (in die bespreking van die profete) na vore bring, doen hy dit deur juis die profeet in anti-tese tot die priester te stel en aan die priester die ware persoonlike Godsgemeenskap te ontsê. 
Hierin verraai hy myns insiens, ironies genoeg. dat juis hy self een van die belangrikste elemente van die Ou-Testamentiese Godsopenbaring verontpersoonlik en versaaklik en nie die persoonlike faktor daarin voldoende raaksien en daarmee genoeg rekening hou nie.

9. Skrywer se beskouing lei tot ' $n$ onderwaardering van versoening deur 'n middelaar, geringskatting van die priesteramp, fundamentele teëstelling van profeet en priester, en ooraksentuering van die ontwikkelingsaspek (evolusie) in die profetiese prediking.

Omdat bogenoemde beskouing nie voldoende oog het vir die absolute karakter van die sondeval van die mens in die koninkryk nie, het dit ook nie voldoende oog vir die noodsaaklikheid van 'n middelaar wat hierdie andersins onoorbrugbare kloof tussen God en mens kan oorbrug nie. Gevolglik lei dit tot onderwaardering van versoening deur 'n middelaar en 'n geringskatting van die priester$a m p$. Skrywer sien selfs 'n fundamentele teenstelling tussen priester en profeet. Op bladsye 167 en 168 van OOT stel hy dit soos volg (al die onderstrepings is deur hom): „By hierdie profeet (Amos, J.L.H.) gaan die stryd om die ware geloof. Die vroomste vroomheid van sy volk word as goddeloos verwerp, want alles wat van die ware God aflei voer na die dood. ,Soek Bet-el nie' (Amos 4:4). Daarteenoor stel hy die boodskap van die lewe: ,Soek My, dan sal julle lewe' (5 : 4). Dit is opmerklik dat die profeet nie tot die soek van Jerusalem (contra Bet-el) opwek nie. Sy God is onafhanklik van 'n kultusplek. Hier het ons die stryd tussen profeet en priester, wat deur die eeue sal duur - die godsdiens wat die HERE aanbid in Gees en in waarheid en dié wat berus by seremonies wat met die loop van die tyd verstar en die lewe van die profesie uitdoof".

„En tog speel in Bet-el 'n stryd af wat deur die eeue sou duur die stryd tussen profeet en priester wat reeds by Moses begin het. Die priester sê: God is te groot en die altaar te heilig dat die mens sonder meer mag naderkom. Die gelowige volk word dan gedegradeer tot „leke" wat 'n bemiddelaar tussen hulle en hul God noodsaaklik maak - die priester! Die profeet verkondig ook die heilige God maar hy verklaar dat die Heilige juis die mense in sy onmiddellike nabyheid wil sien. Soek My! En voor hierdie geweldige majesteit is daar geen onderskeid tussen die mense nie.

Die priester glo aan die medewerking van die gelowige en dit vind juis in die erediens plaas - hier lewer die mens 'n prestasie. Die profeet verkondig: sola gratia, deur genade alleen! Die kloof wat daar tussen God en mens is kan nie deur priesters verbreek word nie, maar deur God alleen.

Die priester verteenwoordig ' $n$ starre tradisie en daarom is daar ' $n$ algemene neiging by gelowiges deur die eeue om maar in salige vrede te berus by die seremonies wat langs die weg van tradisie geërf is. Hier kan die mens aan sy gewoontes vasklem sonder om sy hart te verander. Hy kan sekerheid verkry sonder eie verantwoordelikheid. 
Die profeet is gewoonlik 'n ,ketter". Hy moet soms 'n breuk met die (sondige) tradisie verkondig. Die feesgangers van Bet-el wil dus van Amos niks weet nie.

Maar dit is juis die besondere Godsverkondiging van die Bybelse profete dat daar 'n fundamentele verskil tussen profetiese en priesterlike religie is".

Hierdie laaste stelling is strydig met die gees van die O.T. Hier word sekere uitwasse van die priesterskap geneem en daaruit algemeen geldige gevolgtrekkings gemaak. ('n Mens sou egter net so maklik die teenoorgestelde prentjie kon kry deur die valse profetedom teenoor die suiwere priesterdom te stel!)

'n Mens kan sodanige stelling alleen maak as jy nie voldoende oog het vir die absolute doemwaardigheid van die mens en die gevolglike behoefte aan ' $n$ middelaar tussen God en mens nie, en as jy voldoende oog het vir die versoeningsdiens wat die priester uitoefen nie. Die priesterdiens en die offerande is tog deur God gewil. Abel het reeds 'n offer gebring wat deur God aangesien is. God se belofte dat alle wesens nie weer deur 'n vloed sal vergaan nie omdat die versinsels van die mens se hart sleg is van sy jeug af, word juis direk aan Noag se offer gekoppel (Gen. $8: 21$ ). Abraham moet 'n offer aan God kring: sy seun! En God sien nie van die eis van die offer af nie, maar voorsien (slegs) 'n middelaar (ram) „in die plek van sy seun" (Gen. 22). Die Lydende Kneg bring juis verlossing deur Homself as skuldoffer aan te bied (Jes. 53 : 10).

Die offerdiens het wel in die N.T. verval, maar dis nie omdat dit die vrug was van 'n ontwikkelings-(evolusie-)proses in die denke van die gelowiges oor die saak nie, maar die vrug van die offer van Christus wat toe as Middelaar in vervulling laat gaan het dit waarheen die vroeëre bemiddeling deur priester en offer heengewys het. Christus bevestig dus die Ou-Testamentiese priesterlike bemiddelings- en offerdiens. Slegs vanaf die tyd van sý offerande aan die kruis word dit oorbodig. Mense het in die Ou-Testamentiese tyd wel dikwels aan die priesterlike bemiddelings- en offerdiens ' $n$ formele outomatiese werking en 'n primêre betekenis buite die wil van God en die persoonlike gemeenskap met Hom om, toegeken.

Dáarteen het die (ware) profete met reg in opstand gekom en die relatiewe waarde van dié dinge beklemtoon teenoor die een primêre, naamlik die vergewende wil van die persoonlike God. Dit neem egter niks van die feit weg dat hierdie dinge die deur God gewilde media was nie.

Eers Christus - en dan ook Hy alleen - kon hierdie media oorbodig maak, omdat in Hom offerande en offeraar een geword het. In Hom het dit wat die offer simboliseer, werklikheid geword.

Die verkondiging van die O.T. trek dan ook saam in die Lydende Kneg wat verlossing bring juis deur homself bemiddelend as skuldoffer aan te bied (Jes. 53 : 10).

In die aangehaalde gedeelte van die skrywer met sy fundamentele teenstelling tussen profeet en priester, gekoppel aan so 'n radikale afwysing van priesterlike bemiddeling en die aanklag 
van starre tradisie teen die priester sonder meer, openbaar die skrywer 'n ooraksentuering van die ontwikkelingsaspek (evolusie) ten koste van die versoening (versoeningsdiens). (In die lig hiervan moet ook sy volgende stelling bevraagteken word: „So word ons bewaar vir die valse teëstelling waarvolgens die Ou Testament belofte is en die Nuwe Testament vervulling". KG, 12.)

Dit is blykbaar vanweë hierdie ooraksentuering dat hy nie met die priester (as sodanig) en die „priesterlike religie” vrede kan vind nie. Want die priester as sodanig bring beslis 'n sekere konserwatiewe element in die aanbidding of openbaring. Die priester spoor nie in die eerste plek aan tot voortgang of ontwikkeling nie, maar tot terugkeer, omkeer na God, bekering. Die priester roep die mens tot sterwe, dood, offer! Maar dis dan ook alleen langs hierdie weg van sterwe wat opstanding tot 'n lewe van bekering moontlik is. Die aanklag dat die priester 'n ,starre tradisie" verteenwoordig, is egter sonder grond, want die priester- en offerdiens het 'n element wat steeds bo sigself uitwys na die wil van die persoonlike God (net soos doop en nagmaal in die Nieu-Testamentiese tyd - wat eweneens formalisties benader en beoefen kan word, maar dit tog nie in wese is nie). Reeds in verband met die offer van Kain en Abel hoor ons dat God die een aangesien het maar die ander nie.

Dit is wel by uitstek die profeet van wie ons ,nuwe dinge" hoor. Maar dit impliseer nog geen teenstelling of „fundamentele verskil" tussen profeet en priester nie. Dit pas heeltemal by sy taak wat veral behels dat hy teenwoordige historiese gebeurtenisse moes belig.

(Bowendien gaan dit vir die profete nie eerstens om nuwe dinge nie, maar om die regte persoonlike verbondsverhouding met God. Daarom is dit juis een van die kenmerke van hulle prediking dat hulle die volk terugroep na die ou paaie. Die profeet Jeremia wat met klem die „,nuwe verbond” verkondig (Jer. 33) roep juis sy volk tot so 'n terugkeer op (Jer. $6: 16)$.)

Dit is ook so dat hy 'n nuwe, 'n historiese, perspektief in verband met die versoenings- en offerdiens ontvou. Trouens dis God wat aantoon dat die bemiddelende offerdiens nie slegs kultiese betekenis het nie, maar dat dit ook 'n sekere vergestalting kry in die geskiedenis van die volk Israel. Die profete stel heel dikwels die bemiddelingsposisie van Israel in verband met die nasies (mensdom) se versoening met God. Die ballingskap word gesien as straf van God en wel in so 'n mate dat dit die dood van Israel beteken (Klaagl.; Eseg. $37 \mathrm{vlg}$.). Tog word dit tegelyk 'n opstanding (Eseg. 37). Behalwe die oordeelsaspek bring die profete ook 'n bemiddelingsaspek in hierdie lotgevalle van Israel na vore. Veral Jes. $40 \mathrm{vlg}$. sien daarin vir Israel 'n knegs-taak. Die volk word in sekere sin gesien as 'n offer ter wille van die versoening van die nasies.

Hulle lyde is nie slegs oorsaaklik (straf) nie, maar tegelyk teleologies. Hulle moes dit nie bloot ondergáán nie, maar kon dit aktief aanvaar as 'n tyd van selfverlies en selfverloëning ter wille van 'n doel (vir die nasies), 'n offer wat hulle op die altaar moes lê, 'n priesterlike taak. 
Maar hier word ook duidelik dat - net soos in die geval van die offer in die kultus - die offeraar of offer nie self sy opgelegde diens kan uitvoer nie, maar dat dit oorgaan op die Persoon, die eintlike Kneg, die Lydende Kneg (Jes. 53) wat die offer in sy volle diepte tot vergestalting laat kom en sodoende ook vir die offeraar self versoening bewerk. Verre daarvandaan dat die profeet dus die priester in die ongelyk stel, bevestig hy die priesterlike diens deur die diepte daarvan te ontvou.

Daar waar die Ou-Testamentiese verkondiging saamtrek (Lydende Kneg) het bemiddeling, versoening, offer 'n integrerende plek. Ook die indiwiduele gelowiges se verlossing is vrug van hierdie bemiddeling. Dis slegs as vrug van hierdie plaasbekledende lyde van die Kneg (Jes. 53) wat hulle die uitnodiging ontvang: „O Almal wat dors het kom na die waters..." (Jes. 55: 1 vlg.).

Dit kulmineer in 'n Persoon. Maar - om dit nogmaals te benadruk - dis ook eers die bemiddelingsdaad van dié Persoon, wat as offer kon sterf en daarna kon leef en wat deur sy Heilige Gees in sy gelowiges gestalte kry sodat ook hulle sterf en tog leef dis eers déur en ín Hom wat die bemiddelingstaak van die OuTestamentiese priester en sy offerdiens vervul is en daarom kon en moes verval.

In die skrywer se beoordeling van die priesterskap maak hy, ironies genoeg, dieselfde fout as die formalistiese priesterdom, deurdat hy hulle formalistiese benadering as die wese van die priesterdom as sodanig beskou.

Dit is ironies dat die skrywer dit wat die O.T. wel as 'n balans sien (priester-profeet), tot ' $n$ teenstelling maak; maar dit wat die O.T. as teenstelling sien (goed-kwaad; vgl. die skrywer se verklaring van lig en duisternis in Gen. 1 en die afwisselende verhouding daarvan elke dag), saamvoeg tot 'n balans. Maar - soos uit die betoog tot hiertoe blyk - die een is 'n konsekwensie van die ander.

10. Onderaksentuering van die absolute doemwaardigheid en verdorwenheid van die mens in die stel van die Ou-Testamentiese openbaring aangaande die mens.

Dit is in die lig van die skrywer se verklaring van Gen. $1: 2$ geen wonder nie dat daar by hom tekens op te merk is van 'n onderaksentuering van die absolute doemwaardigheid en verdorwenheid van die mens, vgl. sy bespreking van Ou-Testamentiese openbaring aangaande die mens (hoofstuk XVIII, p. 248-255).

Hy gee daarin 5 onderopskrifte: 1. Die mens byna Goddelik. 2. Die morele sin van die mens. 3. Enkeling en gemeenskap. 4. Die mens as swakke sterwelinge. 5. Ewigheidsverwagting vir die mens?

Gesien die aksent van Gen. 3 vlg. op die verdorwenheid van die mens sou ons hier minstens 'n onderopskrif van dié aard verwag: Die mens as gevalle sondaar, of: Die mens as verdorwe sondaar. Die naaste wat 'n opskrif daaraan haal, is egter: „Die mens as swakke sterweling". En die halwe bladsy wat daaraan gewy word, handel eerstens oor die mens as nietige wese; soos hy 
in Ps. 8 geteken word. Daarna word G. E. Wright aangehaal, wat tereg beweer: „The problem of man is the Bible's central concern. Why is this noble creature of God confronted with so much misery, trouble and sorrow...? The focus of attention is not on the worth of man. It is rather on man's sin, God's judgment, His gracious promises of salvation and their fulfilment". Benewens die twee sinnetjies onder die bespreking van: „Ewigheidsverwagting vir die mens?": „Vanweë sy sonde is die mens van hierdie lewensboom verwyder. Die mens is dus self oorsaak daarvan dat hy moet sterwe", is dit egter die enigste aandag wat hierdie belangrike aspek van die mens in die bespreking van 7 bladsye ontvang.

"Openbaringsgeskiedenis van die Ou Testament" is 'n boek met baie mooi kwaliteite en een waarin die skrywer die grootheid van God duidelik na vore laat kom (vgl. my resensie daarvan in: „In die Skriflig", Des. 1969).

Ongelukkig ondergaan mens se lof vir die werk 'n belangrike beperking by die ontdekking dat leemtes soos in genoemde resensie aangetoon, blykbaar binne 'n legkaart inpas as konsekwensies van 'n eksegese van Gen. $1: 2$ vlg. wat aan die O.T. vreemd is.

11. Die gedagte van die koninkryk kan alleen verstaan word as uitgegaan word van die goeie skepping van God, wat saamtrek in die skepping van die mens na Gods beeld, dit wil sè tot persoonlike verbondsgemeenskap met God, wat deur die ongehoorsaamheid van die mens aan God 'n breuk ondergaan het, so radikaal dat alleen versoening van die mens met God, en dan ook alleen deur ' $n$ middelaar wat die andersins onoorbrugbare kloof oorbrug, tot herstel kan lei. Hierdie twee lyne: persoonlike gemeenskap tussen God en mens, en die versoening van die verdorwe, doemwaardige mens met God, (of, anders gestel: genadeverbond,) moet dwarsdeur die O.T. vasgehou word. Alleen so kan die kruis van Christus en sy liggaam, die kerk, uiteindelik die sentrale plek in die koninkryk inneem wat dit toekom.

Pretoria, Des. 1969.

J. L. Helberg. 